\title{
Dikes and Dams, Thick with Politics
}

Citation for published version (APA):

Bijker, W. E. (2007). Dikes and Dams, Thick with Politics. ISIS. An International Review Devoted to the History of Science and its Cultural Influences, 98, 109-123. https://doi.org/10.1086/512835

Document status and date:

Published: 01/01/2007

DOI:

$10.1086 / 512835$

Document Version:

Publisher's PDF, also known as Version of record

\section{Please check the document version of this publication:}

- A submitted manuscript is the version of the article upon submission and before peer-review. There can be important differences between the submitted version and the official published version of record.

People interested in the research are advised to contact the author for the final version of the publication, or visit the DOI to the publisher's website.

- The final author version and the galley proof are versions of the publication after peer review.

- The final published version features the final layout of the paper including the volume, issue and page numbers.

Link to publication

\footnotetext{
General rights rights.

- You may freely distribute the URL identifying the publication in the public portal. please follow below link for the End User Agreement:

www.umlib.nl/taverne-license

Take down policy

If you believe that this document breaches copyright please contact us at:

repository@maastrichtuniversity.nl

providing details and we will investigate your claim.
}

Copyright and moral rights for the publications made accessible in the public portal are retained by the authors and/or other copyright owners and it is a condition of accessing publications that users recognise and abide by the legal requirements associated with these

- Users may download and print one copy of any publication from the public portal for the purpose of private study or research.

- You may not further distribute the material or use it for any profit-making activity or commercial gain

If the publication is distributed under the terms of Article $25 \mathrm{fa}$ of the Dutch Copyright Act, indicated by the "Taverne" license above, 


\title{
Dikes and Dams, Thick with Politics
}

\author{
Wiebe E. Bijker
}

19 September 2006

(forthcoming in Isis, March 2007: focus section on Thick Things)

Dikes and dams, levees and anicuts, storm surge barriers and tanks - these are thick things. ${ }^{1}$ Most of them are thick in size, such as the hundreds of kilometers length of dikes to keep the water out of the Netherlands. (Some things were not thick enough though, such as the levees to keep the water inside the Mississippi River and the New Orleans canals in 2005. ${ }^{2}$ ) All of them are thick in connections and linkages: like the anicuts that form crucial starting points for networks of irrigation canals and tanks in South India. All of them are thick with values, such as the Oosterschelde storm surge barrier that is hailed as a celebration of modern environmental democracy in the Netherlands. All of them are thick with power, such as the tank systems for irrigation that reflects the power relations in rural Indian. And, surely, all of them are thick with politics.

This essay is meant to support the claim that studying artefacts - their being socially constructed as well as their shaping society-yields crucial insights into the history and development of science and into the history and development of societies. More specifically I want to argue that a focus on things of water management can help us to understand the cultural and democratic make-up of societies, and at the same time is important for addressing questions of further socio-technical development of those societies. While moving my empirical focus between rural India, the United States of America, and the Netherlands, I also want to make the additional point that the normatively used labels 'modern' and 'traditional' are not very helpful in designing technology policies for development. Second, I want to argue that 'development' can be used fruitfully as a more symmetrical concept than in phrases like 'development aid' or 'under-developed countries': when analyzing things and tracing how they are socially shaped and how they help to constitute society, comparative studies about cases in 'the north' and 'the south' can benefit all nations in their development.

\section{Anicuts}

Wherever water is flowing, silting is a problem. Tidal flows, for example, transport sand along coasts, which then ends up silting harbors. Canals that divert water from rivers to irrigate areas of agricultural land will often quickly silt because of the sediments transported downstream. To desilt irrigation canals by dredging is

\footnotetext{
${ }^{1}$ I am grateful to Esha Shah, Shambu Prasad, Chitra Krishnan, and Himanshu Thakkar for their helpful comments on an earlier draft of this essay.

${ }^{2}$ Some things are too thick to deal with in this essay. The Narmada Dam system in northwest India deserves an essay, an article, a book, a library of its own. For an eloquent and fiery indictment, see Arundhati Roy, "The Greater Common Good," in The Algebra of Infinite Justice, ed. Arundhati Roy (Delhi: Penguin Books, 1999). For the other side's view, see the website on the Sardar Sarovar, the largest dam of this system which is currently completed in the midst of legal fights, hunger strikes, and technical controversies: http://www.sardarsarovardam.org/. To follow these fights, see http://www.narmada.org/, and the publications of the South Asia Network on Dams, River and People: http://www.sandrp.in/.
} 
extremely expensive and thus effectively impossible. The alternative is to use things: cleverly positioned dams to steer the sand transportation away from the harbor, or cleverly shaped anicuts to influence the distribution of sediments between the main river and the diverting irrigation canal. ${ }^{3}$

When designing irrigation systems, two problems have to be dealt with: how to get water to dry places, and how to prevent excess water to make those places too wet. To divert water from a river to the agricultural area that is to be irrigated, an outlet from the river into a canal is constructed. Often an anicut or weir is used to control the water level and flow at that point: a dam across the river, just after the canal exit. ${ }^{4}$ The anicut keeps the water level high enough to feed the canal even in dry seasons, while excess water is allowed to spill over and continue downstream (see

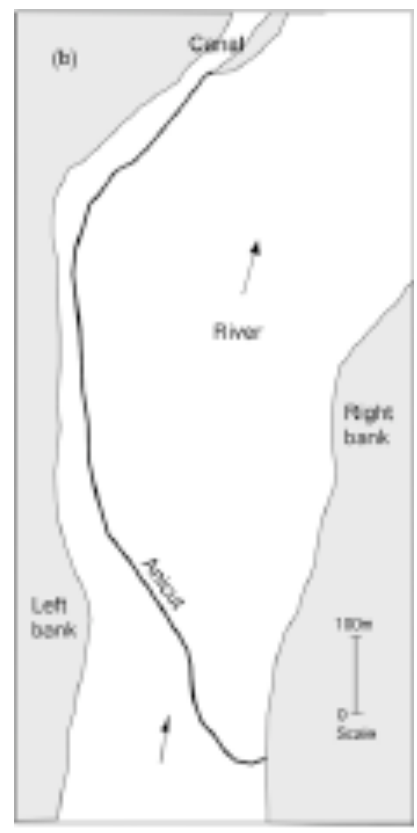

Figure 1 Irregularly shaped traditional anicut. Scale in meters.

figure 1). Here the problem of silting appears: when any sediment carrying flow divides, the ratio in which the sediment is divided is different from the ratio in which

\footnotetext{
${ }^{3}$ My discussion of the anicut technology in India is based on the $\mathrm{PhD}$ dissertation by Chitra Krishnan, "Tank and Anicut Irrigation Systems: An Engineering Analysis" (Indian Institute of Technology, 2003). See also Chitra Krishnan and C. Shambu Prasad, "Technological and Policy Implications of Tank Systems: Reflections from Tank Irrigation in Kolar District, Karnataka," in National Workshop on Rejuvenating Tanks for Sustainable Livelihoods Emerging Trends (ICRISAT, Patancheru, India, India: 2006). Chitra Krishnan and Srinivas V Veeravalli, "Tanks and Anicuts of South India. Examples of an Alternative Science of Engineering" (paper presented at the Compas Asian Regional Workshop on Traditional Knowledge Systems and their Current Relevance and Applications, Bangalore, 3-5 July 2006 2006).

${ }^{4}$ The word 'weir' is typically used for straight dams across the river, perpendicular to the riverbanks. Such weirs can be used, for example, to create millponds feeding a side channel to power a water mill. The word 'anicut' derives from the Tamil 'anaikattu', and is typically reserved for longer dams that do cross the river, but may have more complicated shapes.
} 
the water is divided. One branch receives a disproportionate amount of sediment. Generally it is the canal that receives more than its share of sediment. That sediment, too much to be carried by the water, will then be deposited and a vicious circle begins: the canal will become shallower, it will carry less water, and even more sediment is deposited.

How is it possible that some of these irrigation systems in southern India have been functioning for more than thousand years, not being clogged by sediments and without 'actively' being dredged? Would it be possible, Chitra Krishnan asked, to understand this technology and adapt it, so as to help solving the current irrigation problems in India and other dry regions of the world?

One of the anicuts she studied is the Grand Anicut or Kallanai in the Kaveri (Cauvery in English) River in Tamil Nadu, the southeastern state of India. The Grand Anicut is the most ancient surviving irrigation work in the Kaveri River Delta. It is attributed to the Chola king Karikaal, who is believed to have built the structure in the 2nd century. It is considered the oldest water-diversion structure in the world still in use. The Kaveri River passes the historic rock of Tiruchirapalli, and then breaks at the

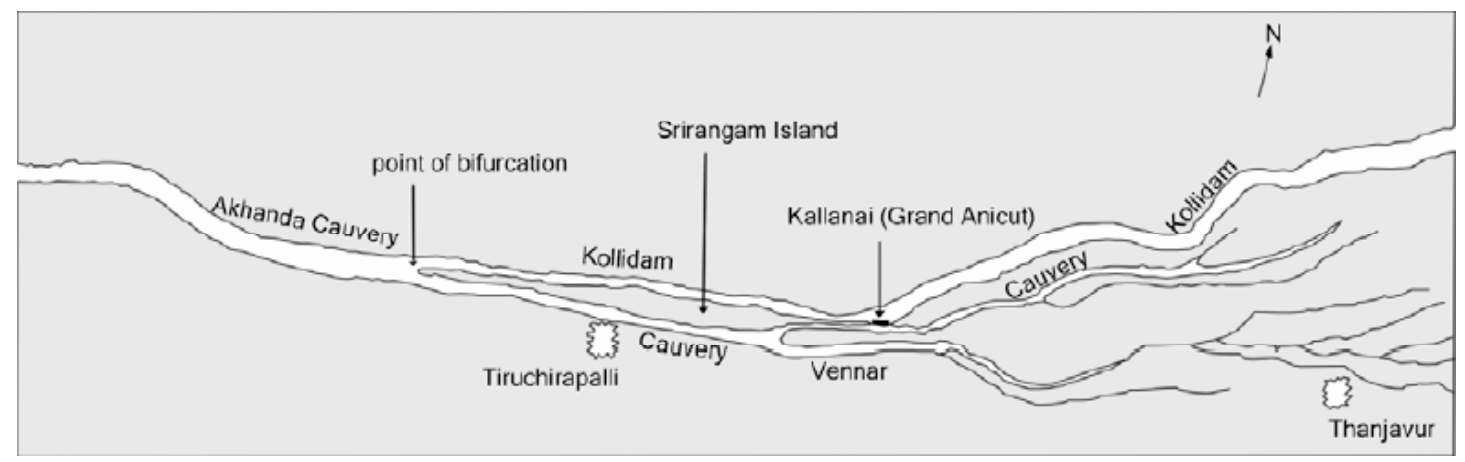

Figure 2 Map of a small section of the Kaveri as it was in 1854 A.D.

The section includes the beginning of the delta (i.e. point of bifurcation)

and the Grand Anicut, $28 \mathrm{~km}$ downstream. It also includes the towns of

Tiruchirapalli and Thanjavur. ${ }^{5}$

\footnotetext{
${ }^{5}$ Courtesy Ibid.
} 


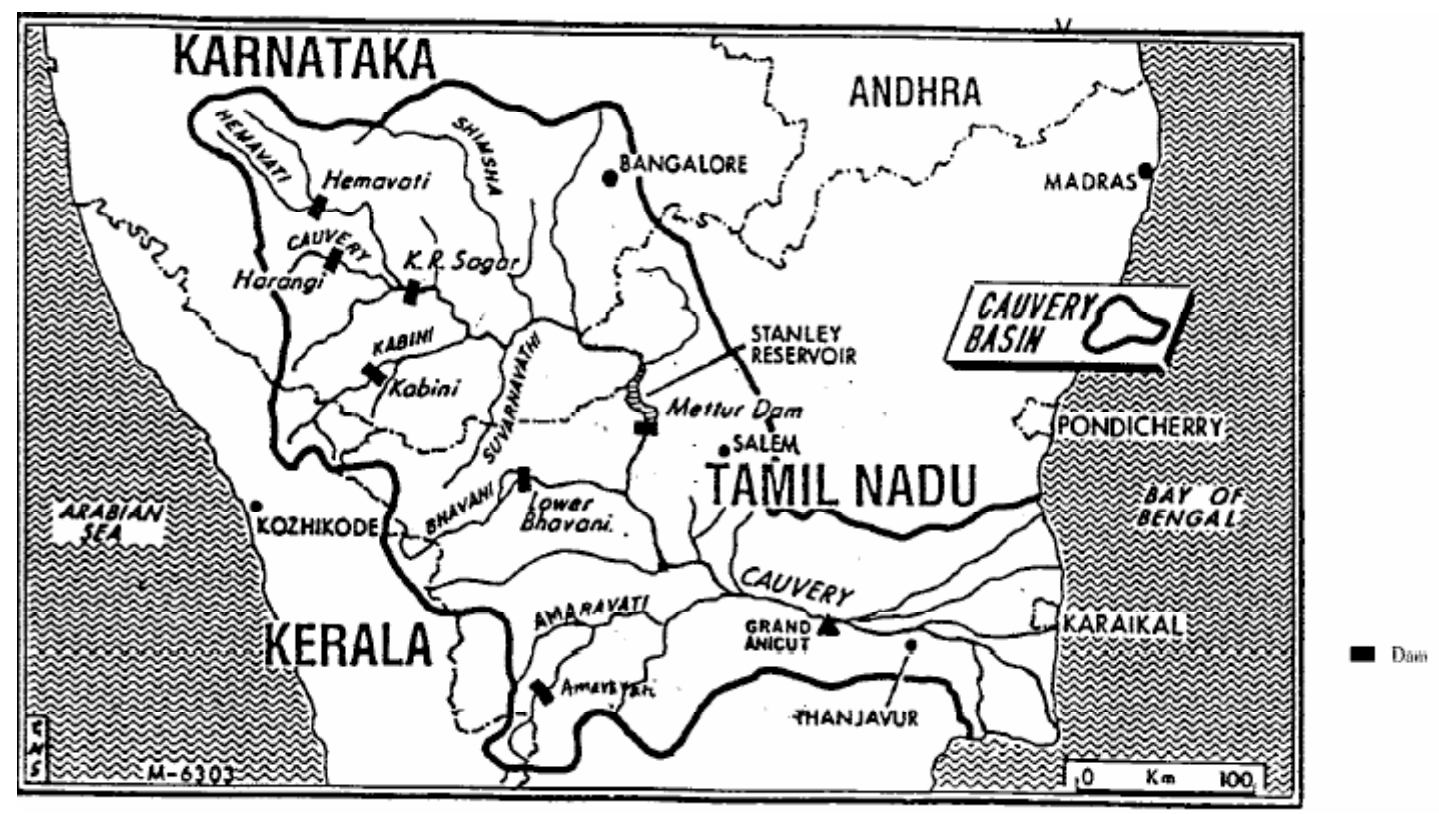

Figure 3 Map of southern India. ${ }^{6}$

island of Srirangam into two streams, which enclose between them the delta of Thanjavur, the granary of South India (see figure 2). The northern branch is called the Kollidam, the other continues as Kaveri. They flow into the Bay of Bengal a few hundred miles south of Chennai (formerly Madras; see figure 3).

The Kallanai or Grand Anicut is an anicut, parallel to the river bank, of unhewn stone in the Kaveri, more than 300 meter long, 20 meter wide, and 4.5 meter high. The purpose of the dam was to divert the waters of the Kaveri across the fertile Thanjavur delta region for irrigation via canals. Since the English arrived in the $18^{\text {th }}$ century, the Kallanai has been tampered with and other hydrological structures have been added nearby. It is therefore difficult to extrapolate from the current situation into the past to understand the workings of the anicut. In her pioneering study, Krishnan combined historical studies of old descriptions of the anicut from a variety of archives with archeological and anthropological field surveys and original hydrological research. This allowed her to piece together a picture of the Kallanai that would explain how it could have been functioning for so many centuries.

She reconstructed the river reach around Kallanai, as it probably was before 1800 (see figure 4). As the figure indicates, Kollidam was the wider (also steeper, straighter and hence faster) of the two branches, and, as its name implies (Koll-idam: region of spill), was the flood carrier. It was barely used for irrigation. Almost all $6,00,000$ acres irrigated by the river in 1800 were delta lands south of the Kaveri branch. So the Kaveri branch was the lifeline for delta farmers, while Kollidam was of little consequence for them.

\footnotetext{
${ }^{6}$ Courtesy Ibid.
} 


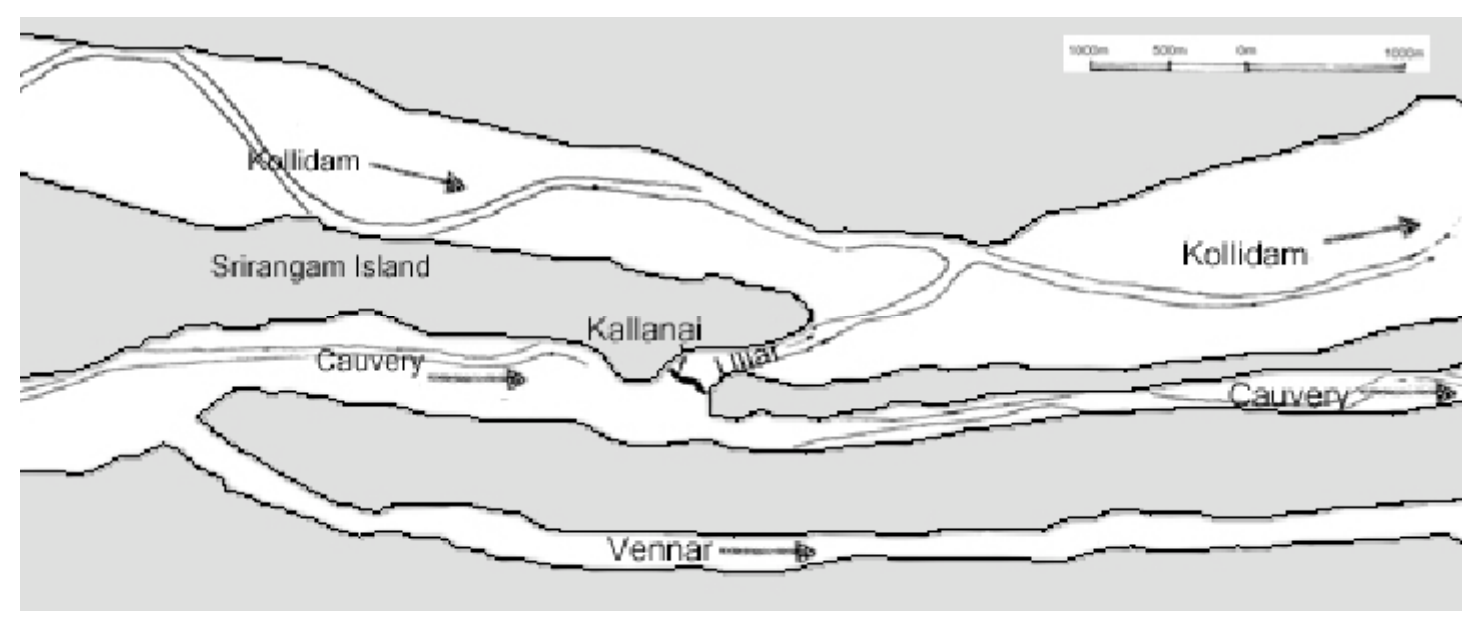

Figure 4 Reconstructed map of the river Kaveri around the Kallanai anicut, before $1800 .^{7}$

Kallanai ensured that during floods, when the water level in the river rose above its crest, a significant part of the water was diverted into the Kollidam from where it could flow directly to the sea and cause the least damage to agriculture. Kallanai's role thus was to prevent the floods in the Kaveri from entering and damaging the irrigated delta by diverting a large part of it into the Kollidam via a short connecting stream. In the 18th century, lack of maintenance probably weakened the Kallanai and diminished its proper functioning. Krishnan conjectures that the sediment carried over

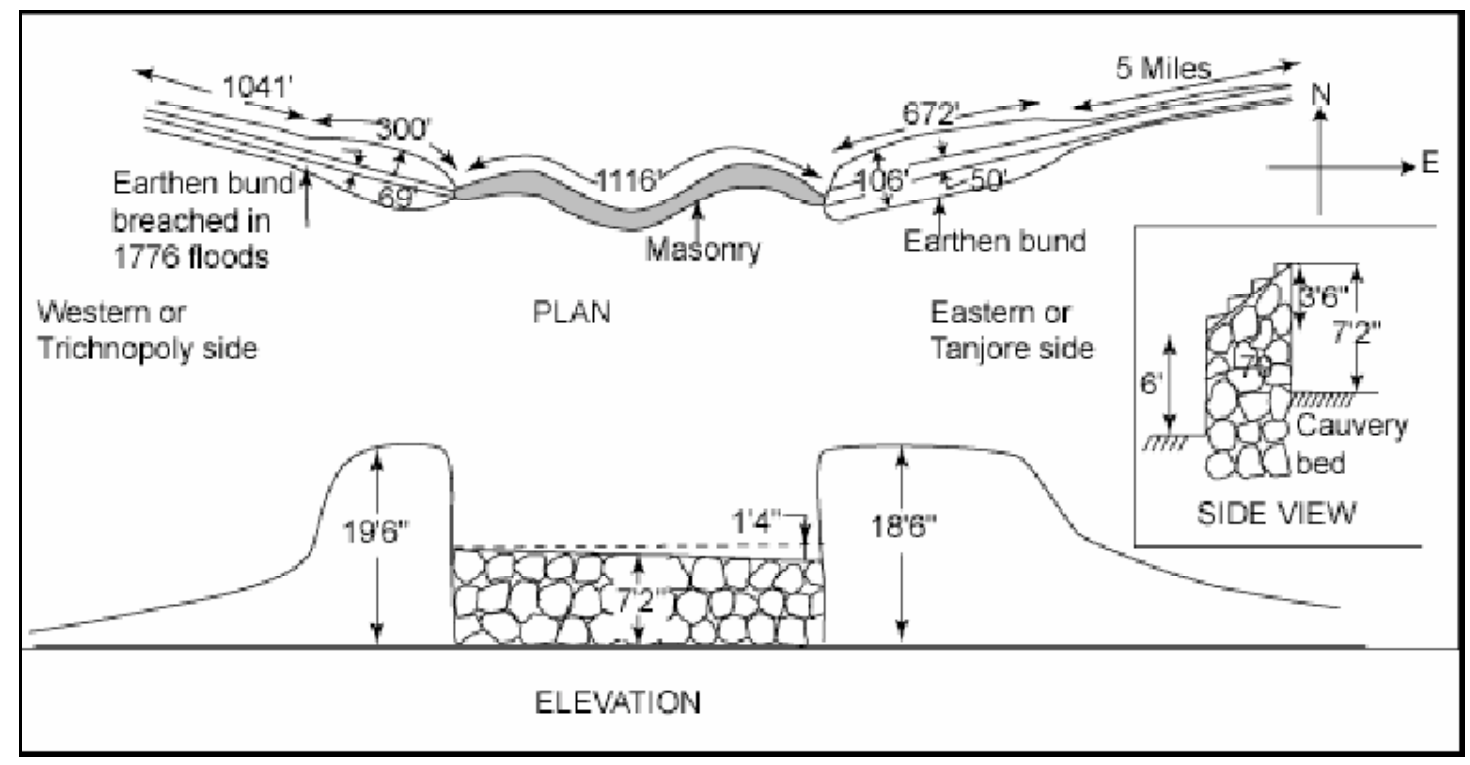

Figure 5 Plan and elevation of the Kallanai, as reconstructed by Krishnan from descriptions of around 1777.

Kallanai (while diverting floodwater) was adversely affected by the first British modifications, after they began ruling the area in 1801 . They did recognize the

\footnotetext{
${ }^{7}$ Courtesy Ibid.

${ }^{8}$ Courtesy Ibid.
} 
problem, but since they probably did not understand the underlying hydrological mechanisms, their modifications only resulted in worse sedimentation. Krishnan has reconstructed the original Kallanai as having very peculiar design features, such as a curved shape of the masonry section, a sloping crest, and an irregular descent from front to rear (see figure 5).

Krishnan then tested some of her ideas, incorporated in this Kallanai reconstruction, in hydrological scale models and by mathematical analysis. The results supported her hypotheses about the beneficial effects of the curvatures in traditional anicuts as compared to straight weirs, on mitigating flood flows and diminishing silting. Further hydrological research, possibly with computer rather than physical models, could detail the fundamental hydrological principles that made traditional irrigation techniques in some respects so effective.

Let me stop to draw some intermediate conclusions. First, it is fascinating to see how a detailed study of this thing, the Kallanai anicut, opens up a view of more than thousand years of irrigation and flood management practices. And Krishnan's investigations really did place the thing at the center: by combining such varied sources as a farmer's family archive, letters from British engineers, her own field measurements and scale model research, she succeeded in reconstructing this artefact that then tells stories about Indian agricultural history as well as hydrological innovations. The second intermediate lesson is that a distinction between 'traditional' and 'modern' technologies does not really help. Is the Kallanai a traditional thing because it was built almost two thousand years ago? But it does seem to incorporate quite advanced hydrological science and engineering - at least in the sense that we need that science to understand why the Kallanai is functioning so well. Krishnan's analysis not only explains the functioning of the Kallanai, but also distills some design principles that can be of use to restore, upgrade or redesign contemporary anicuts. This makes the Kallanai into a starting point for a set of scientific design principles to innovate current flood management and irrigation practices. So, rather than setting apart traditional and modern as incommensurable categories, this case demonstrates a continuum and even complementarity between these types of knowledge.

\section{Tanks}

Let me move on to tanks. ${ }^{9}$ Anicuts are not enough to create irrigation systems: they do allow for flood management, and they do help to steer a relatively small stream of water into an irrigation canal - but then what? Indian farmers use a system of tanks, often linked in long series and networks, to further control on a micro scale the water from these canals to irrigate their farmland (see figure 6).

\footnotetext{
${ }^{9}$ For this section I will draw on the work of another Indian engineer-historian-sociologist: Esha Shah, Social Designs: Tank Irrigation Technology and Agrarian Transformation in Karnataka, South India, Wageningen University Water Resources Series; 4 (New Delhi: Orient Longman, 2003).
} 


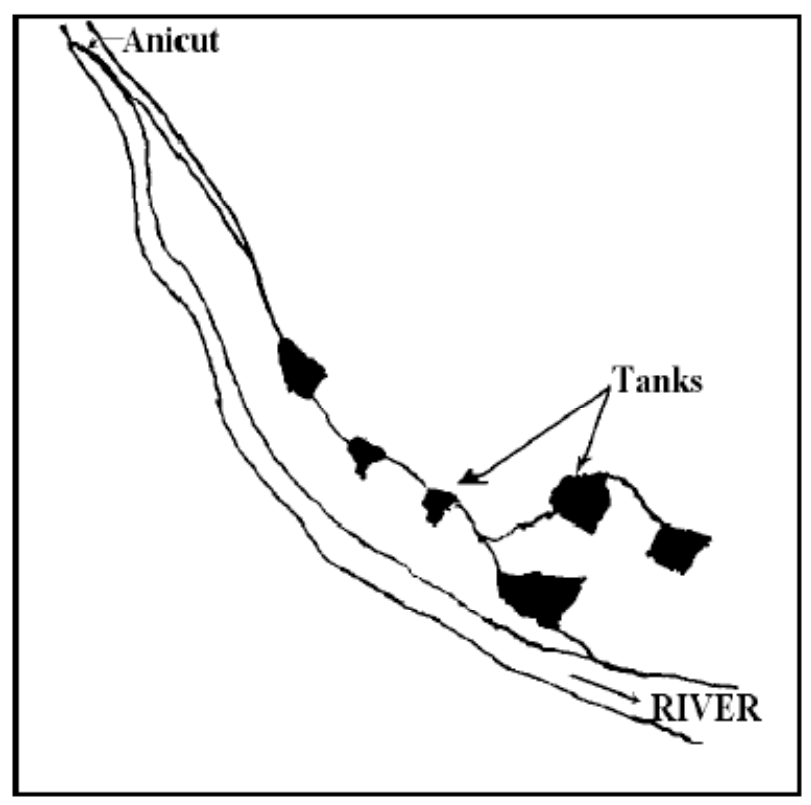

Figure 6 Anicut feeding a tank system. ${ }^{10}$

Tanks are reservoirs for water, often created by building a dam or embankment in a valley or lowered part of the terrain. These tank embankments usually are semicircular or irregularly shaped (see figure 7). They can be a few hundred meters to several kilometers long. An average sized tank in south India has a $2 \mathrm{~km}$ long embankment, a depth of 5 to 7 meters at its deepest point, and may irrigate around 300-350 hectares of land. Tanks usually are located close to villages and have the same name. Typically, the water is also used for domestic purposes.

${ }^{10}$ Courtesy Krishnan, "Tank and Anicut Irrigation Systems: An Engineering Analysis". 


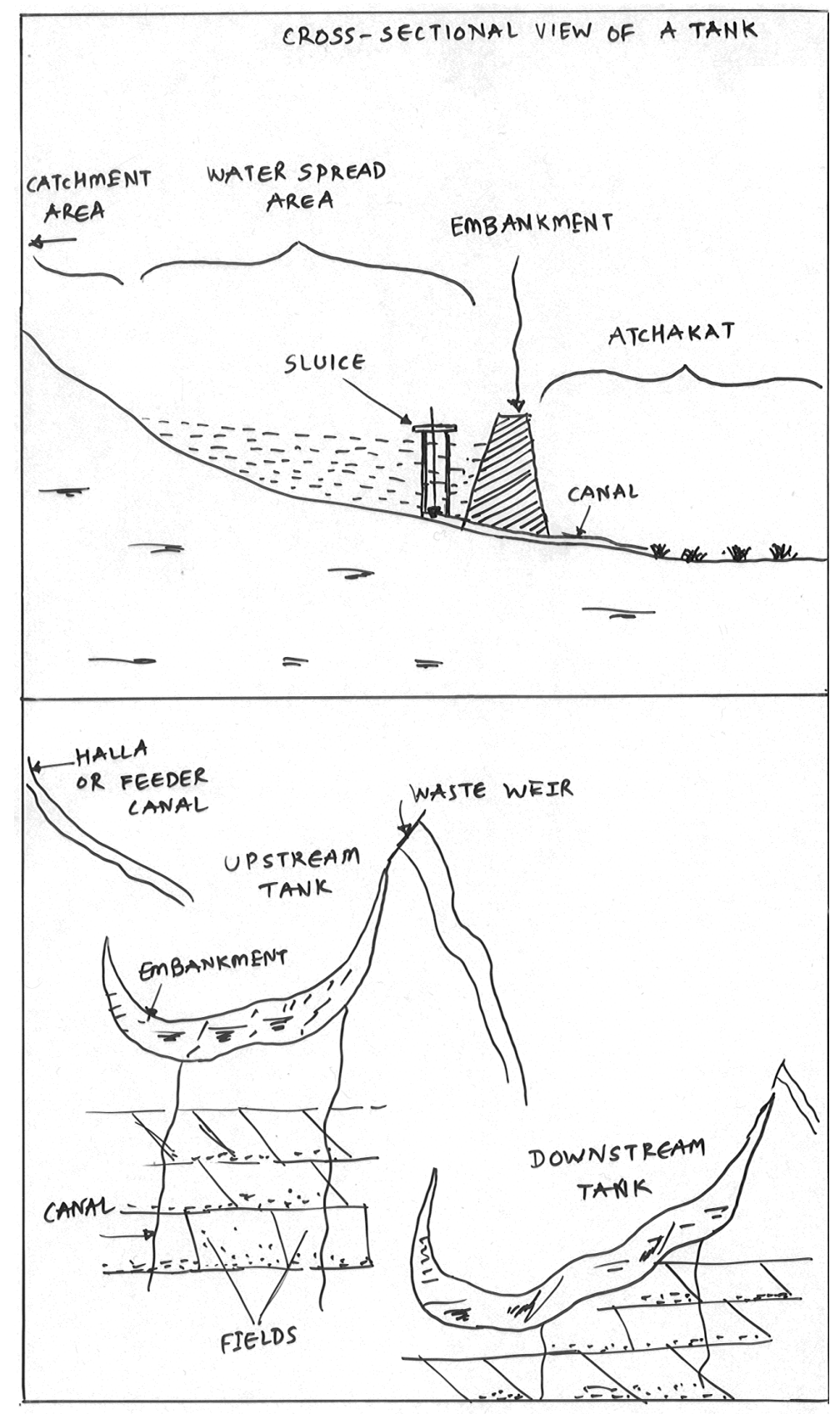

Figure 7 Principle layout of an Indian tank, with feeder canal, embankment, waste water weir, and farm fields. Top: cross-section; bottom: map. ${ }^{11}$

These tanks are equally thick with hydrological ideas and principles as the anicuts, but I want to turn to another aspect of things now. As I have argued elsewhere, things can only be understood by incorporating their social context: they

\footnotetext{
${ }^{11}$ Courtesy Shah, Social Designs: Tank Irrigation Technology and Agrarian Transformation in Karnataka, South India.
} 
are socially constructed, and they shape social relations. ${ }^{12}$ They are, for example, thick with power relations and politics. ${ }^{13}$ In a path-breaking historical sociological study of tanks in Karnataka, India, Esha Shah has sought to understand how social relations of power in particular historical contexts shape tank technology and how technology in turn shapes resource utilization practices in that society. Her starting point is the claim, often expressed in academic and policy circles, that local communities are better versed to manage natural resources than distant state agencies. This view may find support from leftist 'direct democracy' angle, as well as from 'state hands-off' liberal economics corner. Recognizing that Indian society, in the past as well as now, is hierarchically organized and 'anything but egalitarian', she was intrigued by the question of how tanks are used to distribute water resources and how this process may be used to enhance local democracy.

In a careful and detailed analysis, using her sociological and engineering skills, Esha Shah identifies some of the design principles that govern the shape of tanks, and she shows how these principles reflect and reproduce aspects of the local social order. Many south Indian tanks have relatively long embankments - much longer than modern engineering principles would favor. These long embankments, Shah conjectures, were positioned at places that favored the elites of the Hoysala and later Vijayanagara empires that ruled Karnataka between $11^{\text {th }}$ and $16^{\text {th }}$ century: "the site selected for tank construction was primarily a function of political will to invest in that locality and the topographical features of the site played a secondary role." ${ }^{14} \mathrm{~A}$ majority of the existing tanks in Karnataka were constructed between the $9^{\text {th }}$ and $16^{\text {th }}$ century. These ruling elites could afford such design principle that required costly construction of long embankments because they commanded and controlled much of the required labor force of the lower castes. The ruling elite's control over lower caste labour substantially reduced the cost of construction of long embankments. Another design principle pertains to the irrigation method. In a 'field-to-field' irrigation system, fields located in the head-reach would take water first. Neerganti, or watermen, then helped to distribute the water to successive fields, down the slope. This sociotechnical arrangement (including the technology of the tank, the specific layout of the irrigated fields, and the social function of the neerganti) reproduces the social order: "historically and economically privileged groups of farmers own much of the head reach land, [while] lower caste and service caste farmers occupy the [least favorable plots of land at] the tail-end." 15

Though the social order is thus reproduced and solidified in things, it is not cast in concrete. Shah tells a fascinating case in which tail end Muslim farmers successfully used their newly acquired economic might to reverse the social and irrigation order vis-à-vis the historically privileged caste group of Jainas at the head reach, by using hydrological arguments:

"Their challenge to the norm is based on an uncommon interpretation of the way earthen canals function. In their tank, there is heavy seepage from the main canals due to encroachments of canal walls and burrowing actions of

\footnotetext{
${ }^{12}$ Wiebe E. Bijker, Of Bicycles, Bakelites, and Bulbs: Toward a Theory of Sociotechnical Change, Inside Technology (Cambridge, Mass.: MIT Press, 1995).

${ }^{13}$ This point was first made, within a philosophy of technology context, by Langdon Winner, "Do Artifacts Have Politics?" Daedalus 109, no. 1 (1980). See also Wiebe E. Bijker, "Why and How Technology Matters.," in Oxford Handbook of Contextual Political Analysis, ed. Robert E. Goodin and Charles Tilly (Oxford: Oxford University Press, 2006).

${ }^{14}$ Ibid., 38.

${ }^{15}$ Ibid., 269.
} 
rodents. Hence, 'if canals irrigate four hectares, they waste water for four hectares.' Tail end farmers argue that water should be supplied to the tail end because when canals supply water to the tail end, the head and middle reach are automatically irrigated due to heavy seepage."16

But the struggle goes on: there are other stories in which powerful head reach farmers consolidate their social power by removing irrigation canals that would allow tail end irrigation in addition to the field-to-field distribution of water.

Shah pointedly observes that "advocates of indigenous or traditional knowledge rarely mention the grave inequity of traditional India while romanticizing the nature and culture of pre-modern science and technology." ${ }^{\prime 17}$ When tanks, hailed as traditional technology, are approached with such romantic views, their power in reproducing social order may remain unnoticed. When adapting and innovating tank systems for contemporary water management, the use of advanced hydrological research thus is not enough: sophisticated STS research is equally crucial to translate water management technologies into well working and socially embedded solutions for societal problems. ${ }^{18}$ But with such additional insights, these tank and anicut systems do seem feasible and democratic alternatives to the 'temples of modernity' that are so thick with suppressive power. ${ }^{19}$

The third intermediate lesson, then, adds to the previous one: not only is the distinction between traditional and modern technologies difficult to make, the distinction may also blind us to see the values and social orders that are maintained by the things. The distinction between traditional and modern may thus be counter productive when adapting these technologies to solving current water management problems.

\section{Coastal engineering styles in the US and the Netherlands}

The previous two sections in this essay may yield an erroneous conclusion: that we have a value-neutral hydrological science and engineering on the one hand, and the sociological-historical research that deals with the power relations on the other.

Numerous STS studies over more than three decades, on a broad range of topics, have effectively shown that such a distinction cannot be upheld: science and engineering are not value-free; and power relations typically are technologically and scientifically reproduced. I do not want to review that rich body of literature here; I will stay close to my subject matter of water things, and use the example of dikes and levees of New Orleans and the Netherlands to demonstrate how vastly different values may be embedded in seemingly similar things. ${ }^{20}$

How is it possible that American levees failed to keep New Orleans dry, when behind the Dutch dikes large parts of the Netherlands can exist below sea level. Americans also asked this question, and a flock of American expeditions travelled to

\footnotetext{
${ }^{16}$ Ibid., 270-71.

${ }^{17}$ Ibid., 5 .

${ }^{18}$ STS: Science, Technology, and Society studies. My point is not that tanks are inherently iniquitous and non-egalitarian. Rather, that a proper analysis of tanks should also investigate such issues as power relations, and not be blinded by romanticizing the past. Such an analysis could even include a wider social and eco-system than I discussed here. Conflicts between farmers and fishermen might play a role as well.

${ }^{19}$ Cf. note 2 .

${ }^{20}$ For more details, see the research note Wiebe E. Bijker, "American and Dutch Coastal Engineering: Differences in Risk Conception and Differences in Technological Culture," Social Studies of Science (forthcoming in 2006).
} 
the Netherlands in the aftermath of the flooding of New Orleans by hurricanes Katrina and Rita in 2005. The big US television networks, channels such as National Geographic, and political delegations, including the Louisiana governor and members of the US Congress, visited the Netherlands within a few months after the flooding, and all parties returned with spirited reports of how the Americans could learn from the Dutch. Does this suggest that the Dutch dikes are simply better than the American levees ${ }^{21}$; or that the US Army Corps of Engineers is less able than the Rijkswaterstaat engineers in the Netherlands? I will show that something else is going on.

A detailed analysis of two internal histories of coastal engineering in respectively the US and the Netherlands reveals, I will argue, that Dutch dikes and American levees incorporate very different sets of values - values about land and people, about vulnerability, about dealing with risk and uncertainty. ${ }^{22}$ These different value systems are at the core of coastal engineering science and practice. In 1996 the $50^{\text {th }}$ anniversary of the International Conference on Coastal Engineering was celebrated with a 'Silver Conference', ICCE96, in Orlando, Florida. The proceedings of this conference document the history of coastal engineering in the 15 countries that have hosted the ICCE since its first meeting in 1950, in Long Beach, California. I will compare the American and Dutch articles. ${ }^{23}$

Though both articles are primarily meant to provide internal histories of coastal engineering, a few non-engineers figure in the narratives. And already these different non-engineering characters seem to shed a telling light on the relations between the dikes and the people. In the American chapter, they are the 'beach users' who "were visitors on holiday, who had little knowledge of what occurred during hurricanes or winter storms (such as "northeasters"), and little interest in funding studies and works'. ${ }^{24}$ The Dutch article begins by quoting the Roman historian Plinius, who describes the Dutch as 'a miserable people [who] live on high hills, or better on man-made mounds, just above the highest water level known by experience'. ${ }^{25}$ The Dutch article continues to discuss the landowners who collectively maintained and managed the dikes and sluices. To this end, the so-called 'water boards' were created that are claimed to be the oldest democratic institution in the

\footnotetext{
${ }^{21}$ I will be using 'dike' and levee' as interchangeable. Both refer to elevated structures (mostly human-made, but sometimes natural) of sand, clay, and/or stone; positioned along river or sea sides, or around polders. Levee probably derives from the French levee, or raised (Chambers $20^{\text {th }}$ Century Dictionary). Dike (or dyke, dik) is similar to the Dutch dijk, which is thought to derive from the Latin figere, cut and then connect; it thus seems related to 'digging in.' The use of 'levee' rather than 'dike' in English may also be spurred by an offensive, slang meaning of dike: lesbian.

${ }^{22}$ This proposition is similar to the seminal work on different national styles of electricity distribution technological systems by Thomas P. Hughes, Networks of Power. Electrification in Western Society, 1880-1930 (Baltimore/London: The John Hopkins University Press, 1983).

${ }^{23}$ Eco W. Bijker, "History and Heritage in Coastal Engineering in the Netherlands," in History and Heritage of Coastal Engineering, ed. Nicholas C. Kraus (New York: American Society of Civil Engineers, 1996).; Robert L. Wiegel and Thorndike Saville, "History of Coastal Engineering in the USA," in History and Heritage of Coastal Engineering, ed. Nicholas C. Kraus (New York: American Society of Civil Engineers, 1996). Eco W. Bijker is Wiebe E. Bijker's father.

${ }^{24}$ Wiegel and Saville, "History of Coastal Engineering in the USA," 519. The brackets are in the original.

${ }^{25}$ Bijker, "History and Heritage in Coastal Engineering in the Netherlands," 391.
} 
Netherlands. ${ }^{26}$ A ruling by count Floris V in 1280 is cited to illustrate the claim that these boards exemplified 'the real democratic attitude in the Netherlands at that time'. This ruling stated that everybody had to pay for the maintenance of the dikes: 'the monastery, the knight, the priest, the common man, everybody alike' ${ }^{27}$

Another striking difference is the way in which each history describes the early days of the field. A large part of the early history in the American article is devoted to beach and sand transportation studies. The emphasis is on scientific research, publications, and laboratory facilities. A key role is played by the Beach Erosion Board (BEB) of the US Army Corps of Engineers (USACE), which was established in 1930. In contrast, the Dutch article only gives research a prominent place when describing the post-war period. The beginning of coastal engineering in the Netherlands is marked by the unfinished manuscript by Andries Vierlingh (1507$1579){ }^{28}$ Vierlingh was a well-educated patrician and gentleman farmer, who also served in high-level public offices. He was, for example, a dijkgraaf: the highest officer serving the previously mentioned elected Water Boards. Making Vierlingh's work central in the early history of coastal engineering in the Netherlands gives the key role to a certain style of engineering practice, rather than to scientific research. This style of practice is captured by Vierlingh's adage 'niet met fortsigheit maar met soetigheit': not with force, but with sweetness. Or, in the translation of the Dutch coastal engineering article: 'Don't fight the sea with brute force but with soft persuasion'. ${ }^{29}$ The author observes that this 'actually is still characteristic for the coastal defence policy in the Netherlands' ${ }^{30}$ He refers, for example, to the strategy of sand suppletion: the Dutch coast of sand dunes is maintained by joining hands with nature - engineers will supply extra sand at strategic locations along the coast, and the tidal currents will distribute the sand to the required places and thus broaden and strengthen the beach and dunes. ${ }^{31}$

A common element in the American and Dutch coastal engineering histories is the central role played by natural disasters. Disasters figure prominently in the thinking of American coastal engineers: 'It is important to collect information on natural disasters shortly after their occurrence, to document events and effects'. ${ }^{32}$ They recognize the boost that disasters can give to public awareness and coastal engineering and research, which 'often is the case after a natural disaster occurs which affects adversely lives and property of many people'. ${ }^{33}$ Central in the article on the history of Dutch coastal engineering, as much as in the general public's consciousness, is the 1953 storm surge disaster, generally known in the Netherlands

\footnotetext{
${ }^{26}$ For a more comprehensive account of the early history of water boards, see Arne Kaijser, "System Building from Below: Institutional Change in Dutch Water Control Systems," Technology \& Culture 43, no. 3 (2002).

${ }^{27}$ Bijker, "History and Heritage in Coastal Engineering in the Netherlands," 392.

${ }^{28}$ Andries Vierlingh, Tractaet Van Dyckagie ('s-Gravenhage, Rotterdam: Martinus Nijhoff, Nederlandse Vereniging Kust- en Oeverwerken, 1579 (1920, 1973)).

${ }^{29}$ Bijker, "History and Heritage in Coastal Engineering in the Netherlands," 395.

${ }^{30}$ Ibid.

${ }^{31}$ The analogy with Chitra Krishnan's analysis of anicut practice in India is striking: one of her conclusions is that old anicuts worked so well because they sophisticatedly reshaped water currents and sedimentation processes, rather than forcefully control all natural elements; these are my words.

${ }^{32}$ Wiegel and Saville, "History of Coastal Engineering in the USA," 550.

${ }^{33}$ Ibid., 549.
} 
as 'De Ramp', 'The Disaster'. ${ }^{34}$ In the early morning of 1 February the dikes in Zeeland, at the southern end of the Dutch coast, broke: sea level reached the top of the dikes, waves started to nibble at the back slope of the dikes, which are not armored by stones, undermining the structure of the dike from the rear, and eventually the sea pushed through. The seawater rushing into the polders several meters below sea level quickly scoured the breaches wide open. In one week, 1835 people drowned, more than 750,000 inhabitants were affected, and 400,000 acres of land were inundated. The effects have been traumatic - at the individual level, for the Netherlands as a country, and for the coastal engineering profession. ${ }^{35}$

Though Dutch and American coastal engineering both have been shaped by the experience of natural disasters, they are strikingly different. The American practice focuses on predicting disasters and mediating the effects once they have happened, in brief: on 'flood hazard mitigation.' Dutch practice is primarily aimed at keeping the water out.

A long string of hurricanes in the 1950's in the US gave rise to a major effort by both the USACE and the Weather Bureau to develop warning systems and protective measures. Several surge prediction models were developed, with differences resulting partly from different needs of the modelers: USACE for protection, Weather Service for warning, Federal Emergency Management Agency (FEMA) for insurance. The resulting 'present day warning systems, and evacuation programs, ... have largely prevented loss of life despite increasingly higher density population of coastal areas'. ${ }^{36}$ In the 1970's and 1980's coastal regulations were established by some states and by the federal government, of which the National Flood Insurance Program (NFIP) appears to form a centerpiece. The intent of NFIP is to:

... reduce future damage and provide owners with protection from financial losses through an insurance mechanism that allows a premium to be paid by those most in need of this protection. This program is based on the agreement that if a community will practice sound floodplain management, the Federal Government will make flood insurance available. ${ }^{37}$

The key phrase in the U.S. is 'flood hazard mitigation', and the key ideas in this discourse are 'prediction' and 'insurance', which suggest that the very fact of flooding is accepted. The risk criterion that is used in designing levees and other coastal defense structures in the US is a 1:100 chance, or a 'hundred year flood'. This criterion is a technical norm, carrying important professional 'weight' among coastal engineers, but it does not carry any legal authority. How different is the practice in the Netherlands: The water should be kept out, at all costs. In the Deltaplan law, the criterion of 1:10,000 was specified: not merely as a technical norm, but as an obligation embedded in the 'Delta Law', unanimously approved by parliament.

\footnotetext{
${ }^{34}$ For a more detailed account of the role of this disaster in the development of Dutch coastal defense and its relation to Dutch democracy, see Wiebe E. Bijker, "The Politics of Water the Oosterschelde Storm Surge Barrier: A Dutch Thing to Keep the Water out or Not," in Making Things Public - Atmospheres of Democracy, ed. Bruno Latour and Peter Weibel (Cambridge, MA: MIT Press, 2005).

${ }^{35}$ Of course, these numbers of casualties are minute in comparison to many flooding disasters that occur elsewhere in the world. But for the Dutch, recovering from the war and rebuilding their nation, it did have a traumatic effect.

${ }^{36}$ Wiegel and Saville, "History of Coastal Engineering in the USA," 538.

${ }^{37}$ Ibid., 555.
} 
Thus the fourth intermediate lesson is that things such as dikes and levees may incorporate different styles of coastal engineering and different value systems. I would even propose that they incorporate different technological cultures in then way they handle vulnerability, risk, and uncertainty. ${ }^{38}$

\section{The Oosterschelde Storm Surge Barrier}

The specific way in which the Dutch deal with the vulnerability of their country, and the risk of flooding, can only be understood by reference to De Ramp. It provided an enormous boost to both the research and the practice of coastal engineering. It also spurred a rather drastic reaction in the form of the Deltaplan, comprising the almost complete closure of the tidal outlets of the rivers Maas and Rijn. This certainly was a more forceful strategy than Vierlingh's 'soft persuasion'. By the 1970's, however, other societal developments, related as much to increased environmental concerns as to a general decrease of respect for authorities, had begun to challenge both the stature of the coastal engineers and the authority of the national agency Rijkswaterstaat, which was responsible for the Deltaplan. A national controversy developed about whether to close the last remaining open outlet Oosterschelde. The solution to that controversy was a storm surge barrier that remained open under normal circumstances, but could be closed by sliding doors when a storm surge was forecasted. This thing not only seemed to restore Vierlingh's principle of soft handling and soetigheit, but also constituted a 'sweet technology' in the sense of a very challenging, advanced, and exciting piece of science and engineering. Once it was built, and the controversy left behind, the Dutch did not hesitate to advertise this structure as the 'eighth wonder of the world.'

The Oosterschelde Storm Surge Barrier is not only promoted as a technological wonder, but was also hailed as a marvelously democratic thing. Mockingly it can be said to represent the Dutch consensus style of politics, because of its literal compromise character as a thing that can be both open and closed. Also, even its technical details were discussed in parliament, almost making it a 'democratically designed' thing. ${ }^{39}$ But most importantly, its operating characteristics are not cast in steal and concrete, but can be modified and thus adapted to changing ideas about safety and ecology. Thus some of the decentralized Dutch political style, as exemplified by the old water boards but immediately after 1953 seemingly demolished, was restored. In 1991 a detailed evaluation study on the functioning of the barrier and its effects on the tidal ecology was published. This report was broadly discussed by civil society organizations, and in the provincial government council. Detailed technical considerations - pertaining to civil engineering, hydrology, ecology, and biology - were presented and discussed: when things really matter, Dutch politics gets down into the technical details of things.

\footnotetext{
${ }^{38}$ In addition to differences in technological culture, geographical differences also play a role: there are no hurricanes in the Netherrlands.

${ }^{39}$ The design that was agreed upon in parliament, however, was deemed impossible by the engineers, who then proceeded to design another open/closed dam. The engineers involved scorned the politicians and generally professed to be sick of politics; but at the same time successful engineers did and do recognize that all things are thick with politics.
} 


\section{Innovating things}

All things discussed in this essay once were innovations; now they are standing practice. They have grown hard and obdurate, difficult to change. ${ }^{40}$ They may even stand in the way of innovation. When things stabilize and grow obdurate, around them stable ways of thinking and fixed patterns of interaction do emerge - I have called these "technological frames. ${ }^{41}$ People with a high inclusion in such a technological frame will find it difficult to imagine other ways of dealing with the world; of using these things radically differently or even not using them at all. Things like anicuts, tanks, and dams have, for example, kept farmers and agricultural engineers caught in the frame of growing rice on inundated paddy fields.

A radically different way of growing rice is currently being developed: "keeping the soil moist but never continuously flooded during the plants' vegetative growth phase, up to the stage of flowering and grain production". ${ }^{42}$ This 'System of Rice Intensification' (SRI) seems to offer an important innovation to grow rice with less input of water and fertilizers. It may help to get around some of the social conflicts around water, like the Kaveri water dispute between the rice-growing states of Karnataka and Tamil Nadu and the small-scale conflicts about irrigation that continuously happen everywhere. Not surprisingly - considering the long-standing practices of inundated paddy-rice growing, bound to so many things - it proves quite difficult to convince mainstream agriculture of the potential value of SRI. ${ }^{43}$

Shambu Prasad, an engineer and STS scholar who teaches in a business school, asks for 'creative dissent' within science to escape the constraints of obdurate things and mainstream thinking, and thus to allow for innovation. ${ }^{44}$ Particularly, he advocates being open to dissenting views so that civil society organizations may have a more positive influence on new scientific and technological developments and thus help these to find a better grounding in society. Current experiments in India to develop a 'science policy for the people' aim at transcending the anti-science attitude that many civil society organizations erroneously have been associated with. These experiments resonate with an active engagement with science and technology by some patient groups in the US and Europe. ${ }^{45}$ In the case of SRI, such engagement

\footnotetext{
${ }^{40}$ For an analysis of various forms of socially constructed obduracy, see A.M. Hommels, Unbuilding Cities. Obduracy in Urban Sociotechnical Change (Cambridge, MA: MIT Press, 2005).

${ }^{41}$ Bijker, Of Bicycles, Bakelites, and Bulbs: Toward a Theory of Sociotechnical Change.

${ }^{42}$ C. Shambu Prasad, "System of Rice Intensification in India: Implications for Promoting Pro Poor Innovation. Report Submitted to United Nations University - Institute of New Technologies, under Dfid Project 'New Insights into Promoting Rural Innovation: Lessons from Civil Society'," (Maastricht: UN University - Institute of New Technologies, 2005), 4. See also C. Shambu Prasad, Prajit K. Basu, and Andy Hall, "Assessing System of Rice Intensification as a Process: Evidence from India" (paper presented at the 4th Annual IWMI TATA Partners Meet on 'Bracing up for the Future', IRMA Anand, 24-26 February 2005 2005). Krishnan and Prasad, "Technological and Policy Implications of Tank Systems: Reflections from Tank Irrigation in Kolar District, Karnataka."

${ }^{43}$ Norman Uphoff et al., eds., Assessments of the System of Rice Intensification (Sri) (Ithaca, NY: Cornell International Institute for Food, Agriculture and Development, 2002).

${ }^{44}$ C. Shambu Prasad, "Dissent and Innovation: Science and Civil Society in India" (paper presented at the International Symposium on The Culture of Innovation in Indian Science and Technology: Opportunities Seized and Opportunities Lost, Hyderabad, 2006).

${ }^{45}$ See about AIDS patients' involvement in scientific research: Steven Epstein, Impure Science. Aids, Activism, and the Politics of Knowledge (Berkeley, CA: University of California Press, 1996). See for the role of patients with muscular dystrophy: M. Callon and
} 
opens up a broad range of innovations, like in the case of the farmers in Mustikovila in Anantapur ditrict: "SRI here was not about getting higher yields than a conventional plot, but more about allowing farmers to mitigate risk and re-establish control over resources. This benefited farmers who over the years had become increasingly dependent on and vulnerable to external agencies." 46

SRI thus shows how thick with politics these things are: tanks, anicuts, canals and dams. But SRI is equally thick with politics. Could SRI mean an increased use of chemicals to fight the weeds that will now not be drowned by the water on the paddy fields? Could SRI mean a loss of employment for women, since inundated paddy cultivation heralded a feminization of labor? Most tasks on inundated paddy fields, like transplantation and de-weeding, are carried out by women. SRI breeds weeds that cannot be as easily uprooted as weeds from inundated fields: they need a bit of force to be uprooted. Hence some experiments with locally invented machines, such as the 'rotary hoe', to provide that extra (male) force to remove weeds. SRI, as any other technique, touches the way labor is socially organized.

The bottom line of this essay, then, is about things being thick with politics. And I mean politics with a lower-case ' $p$ ': not the politics of politicians, but a broad range of politics from micro to macro scale, and relating as much to the power of humans, as to the power of ideas and things. Recognizing that things are thick with politics also draws attention to the crucial relation of things to people, of things needing to be embedded in a culture if you want them to work. To explain the difference between American and Dutch coastal engineering, I suggested elsewhere that the Dutch people generally know more about, and are more actively interested in, coastal engineering than American citizens. ${ }^{47}$ That allows for other (I am not saying 'better' or 'more advanced') coastal engineering things in the Netherlands than in the U.S. A similar conjecture about Indian water management can be made. It may be possible to work out new irrigation schemes that integrate existing tank systems with significantly altered river flow patterns into new and advanced, sustainable tank ecosystems. But this would need to build upon local practices of water management and democracy, for example by giving new roles to neerganti and by training people in new irrigation techniques (like in the previously mentioned Mustikovila example). Could this then be an alternative to the 'river linking' projects that the national and state governments of India (and China) are currently planning and executing, and that seem to be as enormously thick with politics as the Narmada Dam case ? $^{48}$

\footnotetext{
V. Rabeharisoa, "Research 'in the Wild' and the Shaping of New Social Identities,"

Technology in Society 25, no. 2 (2003).

${ }^{46}$ Krishnan and Prasad, "Technological and Policy Implications of Tank Systems: Reflections from Tank Irrigation in Kolar District, Karnataka," 17.

${ }^{47}$ Bijker, "American and Dutch Coastal Engineering: Differences in Risk Conception and Differences in Technological Culture."

${ }^{48}$ Medha Patkar, ed., River Linking: A Millennium Folly? (Mumbai: National Alliance of People's Movements, 2004).
} 